\title{
ERRATUM
}

\section{Prenylated flavonoids and related compounds of the Indonesian Artocarpus (Moraceae)}

\author{
Euis H. Hakim · Sjamsul A. Achmad · Lia D. Juliawaty · Lukman Makmur • \\ Yana M. Syah · Norio Aimi · Mariko Kitajima $\cdot$ Hiromitsu Takayama $\cdot$ \\ Emilio L. Ghisalberti
}

Published online: 2 February 2007

(C) The Japanese Society of Pharmacognosy and Springer 2007

\section{Erratum to: J Nat Med 60:161-184 \\ DOI 10.007/s11418-006-0048-0}

There were errors in the original version of this article. The structures in Figs. 3, 11, 17, and 23 were incorrect. The corrected figures are shown below.<smiles>C=C(C)C1Cc2c(oc3cc(O)cc(O)c3c2=O)C2=C1C(=O)C(O)=CC2=O</smiles><smiles></smiles>

Artonin O (49) in Fig.17<smiles>CC(C)=CCc1c(O)c(CC=C(C)C)c2oc3c(c(=O)c2c1O)C(C=C(C)C)Oc1cc(O)ccc1-3</smiles>

31<smiles>CC(C)=CCc1c2oc3c(c(=O)c4c(O)c(c1-2)C=CC(C)(C)O4)C(C=C(C)C)Oc1cc(O)ccc1-3</smiles>

32

Artelastin (31) and Artelastochromene (32) in Fig.11<smiles>CC(=O)c1c2c(cc3c(=O)c4c(O)cc(O)cc4oc13)C(C)(C)OC2=O</smiles>

Xanthonolide and Cyclopentenoxanthone in Fig. 23
The online version of the original article can be found at http:// dx.doi.org/10.007/s11418-006-0048-0.

E. H. Hakim (ه) · S. A. Achmad · L. D. Juliawaty ·

L. Makmur · Y. M. Syah

Natural Products Research Group,

Department of Chemistry,

Bandung Institute of Technology,

Jalan Ganeca 10, Bandung 40132, Indonesia

e-mail: euis@chem.itb.ac.id
N. Aimi - M. Kitajima - H. Takayama

Graduate School of Pharmaceutical Sciences, Chiba University, 1-33 Yayoi-cho, Inage-ku,

Chiba 263-8522, Japan

E. L. Ghisalberti

Chemistry, School of Biomedical and Chemical Sciences,

The University of Western Australia, Crawley

WA 6909, Australia 